\title{
Information Structure and Unmarked Word order in (Older) Germanic \\ Roland Hinterhölzl
}

Humboldt Universität zu Berlin, 23.10.07

\section{$1 \quad$ Introduction}

Basic OV and basic VO order have been accounted for by different settings of the head complement parameter, raising the question of how languages with mixed OV/VO order should be treated. Next to (modern) Yiddish, we find mixed word orders in older stages of the Germanic languages. While mixed word orders in Old English and Old Nordic are subject to thorough investigation and heated debates concerning their correct analysis (cf. Roberts 1997, Pintzuk 1999), the discussion concerning older stages of German has been mute owing to the - as I will show - incorrect assumption that German already was an OV-languages in its oldest accessible stage.

In this paper, I will correct this picture by showing that Old High German should not be analyzed as a language with basic OV-order plus a higher degree of extraposition. The core of the paper thus is a careful empirical investigation of word order variation in the OHGTatian translation which reveals that word order in OHG was determined primarily by information structural restrictions. The most important empirical results are that arguments and predicates, which are not subject to extraposition in modern German, occupy a postverbal position in embedded clauses when they are part of the focus domain of the clause.

The results are then embedded into a phase-based model of the interaction between syntactic, prosodic and information-structural conditions that define the characteristic word order properties of $\mathrm{OV}$ - and VO-languages, without assuming differences in the base structure or a directionality parameter in argument licensing (cf. Haider and Rosengren 2003).

This approach crucially rests on dissociating unmarked word order and basic word order and having the unmarked word order in a language being determined by two types of mapping conditions at the interfaces to PF and LF.

\subsection{Word order Change in Germanic}

One of the most intriguing developments in the history of the Germanic languages, next to the grammaticalization of Verb Second (V2), is the change in basic word order in English and Scandinavian. This development involved a change from the presumed Indo-European basic OV order to the basic VO order in these languages. In this scenario, German (and Dutch) retained (modulo some changes in the application of extraposition) the inherited base order.

The traditional explanation of this phenomenon is to assume that the loss of Case led to a positional marking of grammatical functions. However, this account faces serious difficulties if we consider the development of Dutch and Icelandic, since Dutch has also lost its Case distinctions but retained OV order, while Icelandic has preserved its rich Case morphology, but nevertheless changed to basic VO order (cf. Hroarsdottir 2000, this volume for additional discussion of this issue).

Recently an alternative approach for the change in word order in English was proposed that assumes that the change from $\mathrm{OV}$ to $\mathrm{VO}$ is due to language contact and grammar competition in Early Middle English (EME) (cf. Pintzuk 1999, Kroch \& Taylor 2000). This approach is based on the so-called double base hypothesis (Pintzuk 1999) according to which word order variation follows from the co-existence of competing grammars that differ with 
respect to the head parameter of VP and IP. Within this approach, it is often assumed that VO orders are an EME-innovation that was brought about by language contact between AngloSaxons and the Scandinavian settlers in the $10^{\text {th }}$ century (cf. Kroch \& Taylor 1997, Trips 2002).

\subsection{Word order Variation in Germanic}

If we look at word order regularities in the older stages of the Germanic languages, then we find that both OV- and VO-properties already existed in Old English (OE), rendering the contact scenario from above less plausible. Furthermore, if we look at Old High German (OHG ) and Old Nordic (ON) (cf. Hroarsdottir 2000, 2006) we find a similar kind of variation in word order suggesting that these mixed word order properties should not be treated in terms of language contact, but may simply be part of the common Germanic inheritance. In the following, I will restrict myself to a discussion of word order variation in OE and OHG.

The examples in (1) illustrate typical OV-properties in OE. For example, in (1a) the direct object and the verb particle precede the finite verb in final position within an embedded clause and in (1b) the non-finite verb precedes the finite auxiliary in sentence final position as is typical in OV-languages. The same state of affairs, maybe less surprisingly, also holds in OHG, as is illustrated in (2).

$$
\begin{array}{llll}
\text { a. } & \text { bæt he his stefne up ahof (OE) } \\
\text { that he his voice up raised (Pintzuk 1991:71) } & \begin{array}{l}
\text { red on scippe lædde wæron } \\
\text { b. forPon of Breotone nædran }
\end{array} \\
\text { because from Britain adders } & \text { on ships brought were }
\end{array}
$$
(Pintzuk 1991:117)

$\begin{array}{llllll}\text { a. Soso } & \text { zi In } & \text { gisprochan uuas } & \text { (T 37,5) } & \text { (OHG) } \\ \text { b. how to them } & \text { spoken was } & & \\ \text { b. } & \text { thaz then alton } & \text { giqu\&an } & \text { uúas } & \text { (T 64, 13a) } \\ \text { what to-the old } & \text { said } & \text { was } & \end{array}$

However, we also find ample evidence of properties in OE that one would associate with VOlanguages, as is illustrated in (3). For instance in (3a) and in (3b), the direct object and a small clause predicate follow the selecting verb in an embedded clause. In (3c), the verb particle that is stranded by movement of the finite verb, arguably an instance of V2, does not appear in a clause-final position, as is common in OV-languages, but precedes a (heavy) predicate in that position and in (3d) the manner adverb follows the verb it modifies. These properties are typical of VO-languages.

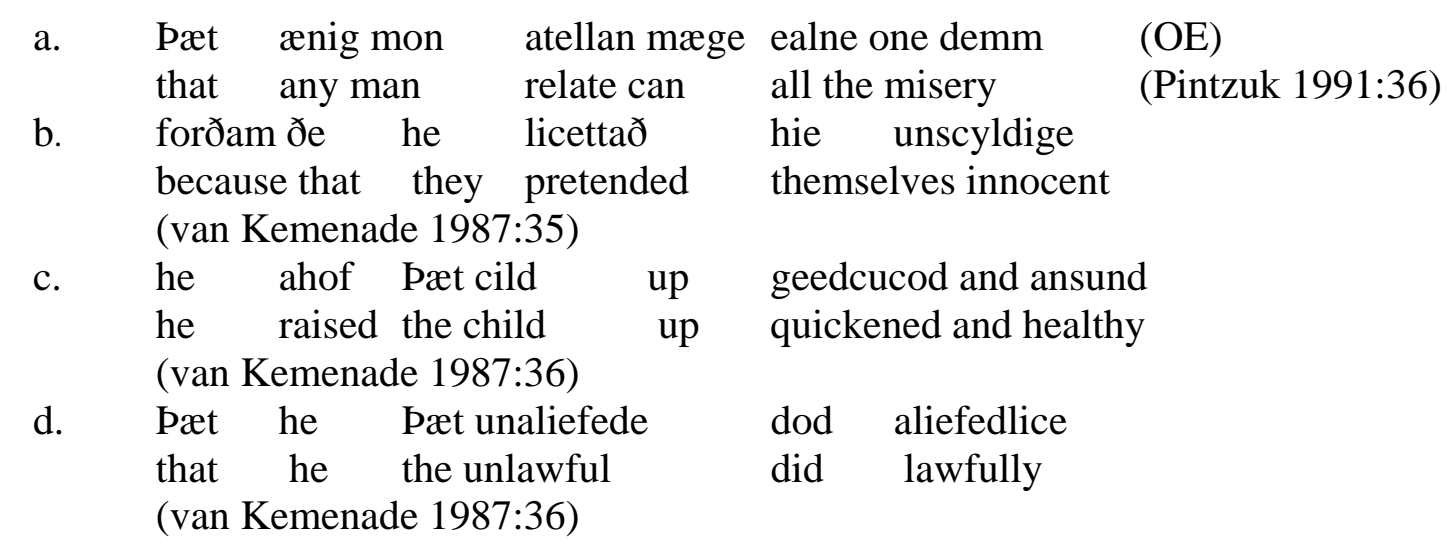


Similar examples can be found in the OHG Tatian text. For example in (4a), the subject follows the selecting verb in an embedded clause and in (4b), the participle follows the selecting auxiliary, an order that is ungrammatical in modern standard German (though there are dialects that allow for right-branching verb clusters), but typical for a VO-language.

a. thaz gibrieuit uuvrdi al these umbiuuerft
that
listed 35,9$)$
b. thas sie uuvrdin $\begin{aligned} & \text { gitoufit } \\ & \text { baptized }\end{aligned}$
that they were

(OHG)

While it has been argued for English that the variation illustrated in (3) should not be accounted for in terms of assuming a basic OV-grammar plus extraposition of heavy material and really calls for the assumption of an additional VO-grammar (cf. Pintzuk 1999), the type of evidence illustrated in (4) has been treated quite differently so far.

The standard treatment of OHG is that of an OV-language that allowed for a greater amount of extraposition than modern German (cf. Lenerz 1984). This view has been reinforced by the first large scale empirical investigation of word order in OHG by Dittmer \& Dittmer (1998). They investigated the syntax of the Tatian translation, the largest document of OHG dated before 850, by considering only data that differ in order from the Latin origin, called deviations here. The Tatian text is often viewed as a slavish translation of the Latin origin and VO properties, as the ones illustrated in (4), have been relegated to Latin influence. However, it has long been noted that the quite frequent deviations from the Latin word order can provide valuable evidence for genuine OHG syntactic structure. Dittmer \& Dittmer have shown that these deviations display features familiar from New High German (NHG) and thereby strengthened the picture that OHG was basically a pure OV-language like NHG.

In this paper I will show that deviations from the Latin word order going against NHG can also be found in significant numbers. In particular, I will provide convincing evidence that OHG had a right-peripheral focus position explaining why and when constituents follow the selecting verb in embedded clauses in OHG. I will then show that the deviations in their totality allow to reconstruct a genuine OHG system in which word order is largely determined by information structural parameters.

\section{Word order Variation and Information Structure}

In this section, I will first argue against accounting for word order variation in terms of multiple bases and propose that variation in word order is better explained as resulting from the complex interaction between prosodic and information-structurally requirements. Furthermore, I will argue that a change from basic OV- order to basic VO-order cannot be equated with a change in the head-complement parameter, but involves differences in a number of properties that are better accounted for by conditions working at the interface to PF and LF. As an alternative, I propose to dissociate base order and unmarked word order and show that information structure play a crucial role in determining what counts as unmarked or marked word order in a language state.

\subsection{Mixed word orders and the double base hypothesis}

An important aspect of the data in (3) and (4) is that we do find not only sentences with pure $\mathrm{OV}$-properties and sentences with pure VO-properties in these languages, but very often we find sentences with mixed word orders. For instance, in (3a) it can be seen that while the direct object follows the selecting verb (and the modal), a typical VO-property, the infinitive 
precedes the selecting modal which is rather typical of an OV-language. In (3d) the direct object precedes the selecting verb, a typical property of an OV-language, while the manner adverb follows the verb that it modifies, which is typical of VO-languages and ungrammatical in OV-languages. Likewise in (4), while the subject follows the selecting verb (and the auxiliary), the participle precedes the auxiliary, as is typical in OV-languages.

Given this state of affairs, the question arises of how to account for mixed word orders in the older stages in these languages. My approach is to assume that OV/VO orders do not signal the presence of two grammars, contrary to the double base hypothesis (cf. Pintzuk (1991), but that the variation illustrated in (1-4) is due to the expression of different information-structural (IS) categories within one grammar. The advantage of this approach is clear when it comes to the characterization of mixed word orders. Proponents of the double base hypothesis not only have to assume that a speaker possesses two grammars or two settings of the head complement parameter, but also that he can switch between the settings of the head complement parameter within one sentence.

To give a concrete example, in order to derive the sequence relate can all the misery in (3a) proponents of the double base hypothesis have to assume that the speaker can switch from an OV grammar - in order to derive the verbal complex Infinitive $>$ finite Modal - to a VO grammar, to account for the object in postverbal position. Note specifically that the assumption of an OV grammar plus extraposition only leads to further difficulties in the double base approach. First, there is the issue that OV languages like German and Dutch do not allow for extraposition of DP-arguments, raising questions about which properties in a grammar allow and constrain extraposition. Second the question arises of which factors determine when a speaker uses extraposition and when he simply switches to a VO-grammar in such a scenario. ${ }^{1}$ Summing up, it would be advantageous if mixed word orders can be accounted for as variation within one grammar.

\subsection{Differences between $\mathrm{OV}$ - and VO-languages}

I have argued in Hinterhölzl (2004) that differences in basic word order should not be explained in terms of the head complement parameter, since OV and VO languages differ in properties that cannot be subsumed under this parameter. First note that adjuncts that can occur between the subject and the vP in VO-languages are subject to restrictions that are absent in OV-languages, as is illustrated in (5). This has first been observed by Haider (2000) and is further discussed in Hinterhölzl (2001). The data in (5) show that the English middle field does not tolerate heavy constituents, while no problem arises in the German middle field.
a. John (more) often (* than Peter) read the book
b. Hans hat öfter (als der Peter)
Hans has more often (than the Peter)
das Buch
the book
gelesen
read

Second, event-related adverbs, that is Time, Place and Manner adverbs appear in the order $\mathrm{T}>\mathrm{P}>\mathrm{M}$ preverbally in OV-languages, but appear in the exact mirror order postverbally in VO-languages (cf. Haider 2000, Hinterhölzl 2002), as is schematized in (6).
a. $\quad \mathrm{C}$
T P M-V
OV-languages
b. $\quad$ C $\quad$ - M P T
VO-languages

\footnotetext{
${ }^{1}$ An interesting alternative proposal within the Kaynean approach is constituted by Biberauer and Roberts (2005). They account for mixed OV/VO orders by assuming a variable degree of pied-piping of a movement operation that involves checking of formal features on the verb. It remains to be seen though how this approach can cope with the adjunct data discussed in Section 2.2 below.
} 
This raises the question of why the placement of exactly these adverbs and not of other, say, higher adverbs seems to be correlated with the head complement parameter. In Hinterhölzl (2002, 2004), I have argued that the order found in German is basic and that the English order is to be derived from the German word order in terms of successive cyclic VP-intrapositon that pied-pipes the adjunct at each step ${ }^{2}$. Furthermore, I have argued that VP-intraposition came about due to a stylistic rule of light predicate raising that was operative in OE and affected typically event-related adjuncts since they were primarily realized as rather heavy NPs and PPs.

Since the head-complement order seems to be connected with properties in the grammar that are quite distinct, I argue that the head-complement parameter should be dispensed with and propose that word order properties should better be defined by globally operating interface constraints.

\subsection{Base order and unmarked word order}

When we dispense with the head complement parameter and adopt the Universal Base Hypothesis (UBH) (cf. Kayne 1994), then it is necessary to distinguish between the base order, which is universally defined as Specifier - Head - Complement, and the unmarked word order of a language. For instance, the unmarked word order in German (OV) cannot be taken to be a basic property (to be identified with the base order) anymore, but has to be derived from other properties in the language.

Nespor, Guasti and Christophe (1996) propose that the head complement parameter is determined by the predominant, that is, unmarked prosodic patterns in an early phase during language acquisition (the rhythmic activation principle). More specifically, they argue that the decisive information for the child is the placement of main prominence within the phonological phrase ${ }^{3}$.

In Hinterhölzl (2004), I have adopted this approach and proposed that the unmarked word orders in the phrases of a language are determined by the predominant, that is, unmarked prosodic patterns in that language.

That a language can have several unmarked prosodic patterns is shown by German. While with DPs and PPs the unmarked prosodic pattern is (weak strong) ((w s)), the unmarked prosodic pattern with VPs is (s w). It is interesting to note that APs show both types of prosodic patterns with a strong preference for the verbal pattern (s $\mathrm{w})$, as is illustrated in (7). (7a) is the neutral order, while (7b) is rather marked and can only be used for specific communicative purposes.
$\begin{array}{lllll}\text { a. weil } & \text { Hans } & \text { [[auf die Maria] stolz] } & \text { ist } \\ \text { b. } & \text { weil } & \text { Hans } & \text { [[stolz [auf die Maria]] } & \text { ist } \\ & \text { since } & \text { Hans } & \text { (of the Maria) proud (of the Maria) } & \text { is }\end{array}$
(unmarked)
(marked)

In conclusion, I would like to propose that syntactic structures are not marked per se (say, in terms of complexity), but count as marked or unmarked if they realize marked or unmarked prosodic patterns. Since the unmarked word order in a language is defined by the

\footnotetext{
${ }^{2}$ In this approach a modern English sentence like (ia) is derived as is illustrated in (ib-e).

(i) a. John visited them in Vienna on Friday

b. [...[on Friday [in Vienna [John visited them $]]]]$

c. $\quad[\ldots$... [on Friday [[John visited them $]$ in Vienna $\left.\left.\left.t_{\mathrm{VP}}\right]\right]\right]$

d. $\quad[\ldots$...[ [John visited them $]$ in Vienna $]$ on Friday $]$

e. $\quad\left[\mathrm{IP}_{\mathrm{P}} \mathrm{John}_{\mathrm{i}}\left[\left[\left[\left[\mathrm{vP} \mathrm{t}_{\mathrm{i}} \text { visited them }\right]_{\mathrm{k}} \text { in Vienna } \mathrm{t}_{\mathrm{k}}\right]_{\mathrm{j}}\right.\right.\right.$ on Friday $\left.\left.\mathrm{t}_{\mathrm{j}}\right]\right]$

${ }^{3}$ To get prosodic bootstrapping off the ground, we have to assume that the child has access to the following universal principle that if a head and a non-head are combined in a single phrase it is the head (or the functional element) that is weak. So if the child encounters the pattern (weak strong), it knows that the head precedes the complement or that a functional element precedes a lexical category.
} 
predominant, that is to say, the most frequent prosodic pattern in a language, the unmarked word order may differ from the universal base order. The frequency component in the definition of the unmarked word order is important for explaining word order change. If a marked prosodic pattern is more widely used and crossing a certain threshold becomes unmarked and may thus give rise to an additional or new unmarked word order. This is the approach to word order change that I will pursue in the following sections.

\subsection{Information structure (IS) and word order}

Since the expression of IS-categories influences the default mapping between syntactic structure and prosodic structures, as I will show below, IS plays an important role in defining marked and unmarked word orders.

Before we discuss the role of information structure in determining word order in OHG, let me point out which factors were thought in the traditional literature to determine word order in these languages. A much quoted point of view is constituted by the observation by Behaghel (1932) that pronouns and unmodified nouns tend to precede the verb, while modified nouns, PPs and other heavy material tend to follow the verb that gave rise to the generalization in (8). The statement in (8) raises a number of questions. First, the question arises which principle of grammar this tendency derives from. Second, note that (8) is a statement that forbids heavy elements in the middle field of OE (as well as in Old Icelandic (OI) and OHG), raising the question of whether there is a connection between (8) and the modern English facts, illustrated in (5) and (6) above. In section 5, I will argue that (5), (6) and (8) can be derived from a prosodic condition on the mapping between syntactic structure and PF.

(8) Light elements precede heavy elements in OE, OI and OHG.

(Behaghel 1932: Das Gesetz der wachsenden Glieder)

There is another generalization that emerges from an IS-analysis of the Tatian translation (to be revised below) that derives (8) as a mere corollary. Given that discourse-given elements are typically realized as light elements, while focused constituents may count as prosodically heavy elements since they receive stress, (9) derives the tendency expressed in (8).

(9) C background V (presentational) focus

The following notions are relevant for an IS-analysis of marked and unmarked word orders. A) The discourse status of an expression denoting a discourse referent: discourse-given elements are assumed to be part of the background, that is, part of the knowledge that is assumed to be shared by speaker and hearer, while discourse-new elements are assumed to be part of the presentational focus of the clause. B) Discourse-given elements can also be made prominent and be part of the focus domain of a clause. A typical case in question is a contrastively stressed pronoun. C) Taking into account the prosodic properties of focused elements, we further need to distinguish between wide and narrow focus. The three different notions of focus relevant here are illustrated in (10): broad and narrow presentational focus and contrastive focus. In (10), brackets mark the focussed constituents and capital letters mark a high pitch accent, which is typical for contrastively focused elements.

(10) a. What did John do? (broad presentational focus) John [gave a book to Mary]

b. What did John give to Mary? (narrow presentational focus) John gave [a book] to Mary 


\section{c. John gave Mary [a BOOK], not a pen (contrastive focus)}

The distinction that prosody makes between narrow and broad focus is relevant for the determining the unmarked prosodic pattern in the clause. Constituents that are broadly focused do not restructure with the verb. They are mapped into prosodic constituents according to the syntactic structure alone, while narrowly focussed constituents integrate into the phonological phrase of the verb (cf. Nespor \& Vogel 1986, Frascarelli 2000). This means that preverbal narrow focus gives rise to the prosodic pattern (s w), while postverbal narrow focus may strengthen the prosodic pattern (w s) in the middle field.

The direction of restructuring of the verb (induced by focus restructuring) is also important for licensing co-predicates of the verb in small clause constructions, verb particle constructions and idioms, determining whether a language counts as OV- or as VO-language on the surface.

The generalisation in (9) allows us to account for word order variation within one grammar by taking into account the information-structural contribution of a constituent in the discourse: for instance, a direct object will precede the verb (in embedded clauses), if it is discourse-given, but will follow it, if it is discourse-new.

According to the generalisation in (8), a direct object will be placed preverbally if it is realized as a pronoun or single noun, but postverbally if it is made heavy by modification. As I have indicated above the two conditions are not independent of each other, but it would be interesting to see which one of them is more basic (see also Hroarsdottir this volume for similar observations in $\mathrm{ON}$ ).

\section{Word order Regularities in the OHG Tatian Translation}

In this section, I will report on the results of an empirical investigation of word order variation in the Tatian translation. ${ }^{4}$ The results are augmented by a small scale information-structural analysis of the deviations noted in the study by Dittmer \& Dittmer (1998). I will concentrate on word order deviations in the clause and disregard deviations within DPs, since these are immaterial for our puposes here. The goal of this section is to provide the reader with a picture of what OHG looked like. As we will see some of the properties are known from modern German while other properties differ quite strikingly from it. How these properties can be explained in a genuine OHG syntax is discussed in Section 4.

\subsection{Systematic Deviations towards NHG}

Here I will discuss the most important deviations in word order from the Latin original that have been noted by Dittmer \& Dittmer. These deviations are all quite systematic and display properties that are familiar from NHG.

\subsubsection{V2 structures in main clauses}

In main clauses Latin word order is regularly converted into V2-structures, as is illustrated in (8). However, we must take note of the fact that the V2 pattern in declarative main clauses has not yet been fully grammaticalized in the OHG Tatian text. In particular, V1-orders appear quite frequently and systematically in main clauses. We will come back to the alternation between V1 and V2 declaratives in Section 4.1. Examples are given in the following way: the

\footnotetext{
4 This empirical investigation was carried out by project B4, „The role of information structure in the development of word order regularities in Germanic" of the SFB 632 "Information Structure: the linguistic means for structuring sentences, utterances and texts” at the University of Potsdam and HU-Berlin (cf. www.sfb632.uni-potsdam.de/projects_b4eng.html).
} 
first line displays the Latin original, the second line its OHG translation and the third line an English gloss of the German text and the pertinent contrasts are highlighted by characters in bold face.

\& repl\&ti sunt omnes
Tho uuurdun $\quad$ sie gifulte alle $\quad$ (T 115,7)
Then became $\quad$ they filled all

\subsubsection{Insertion and placement of personal pronouns}

A subject pronoun that is lacking in the original text is inserted in the translation in most cases, as is illustrated in (12a). In this process, subject pronouns are placed systematically either in the sentence initial position as in (12a), or directly after the finite verb in main clauses and after the complementizer in embedded clauses, as is illustrated in (12b). A pronoun found in the original text in a position different from these designated ones, is regularly moved into the top of the middle field, as is also illustrated in (12b).

$$
\begin{aligned}
& \text { a. pacem relinquo vobis } \\
& \begin{array}{llll}
\text { Ih } & \text { forlazzu } & \text { íu } & \text { sibba } \\
\text { I } & \text { leave } 281,7) \\
& \text { you } & \text { peace } &
\end{array}
\end{aligned}
$$

b. $\quad$ scitis quid fecerim vobis

$\begin{array}{llllll}\text { uuizzut } & \text { ir } & \text { uúas } & \text { ih } & \text { iù } & \text { teta }(\mathrm{T} \mathrm{271,1)} \\ \text { know } & \text { you } & \text { what } & \text { I } & \text { to-you } & \text { would-do }\end{array}$

\subsubsection{Formation of a middle field by preposing of light material}

In this context it is important to note that pronouns seem to be governed by a rule that applies to light elements in general, as is noted by Dittmer \& Dittmer on page $21 .^{5}$ As a case in question compare (12b) in which the light object pronoun $i u$ is placed in front of the finite verb, with (13) in which the rather heavy direct object íuuuere fuozzi remains in postverbal position. In many cases, the preposing of light material leads to the construction of a middle field that is typically missing in the Latin origin, as is illustrated in (14).

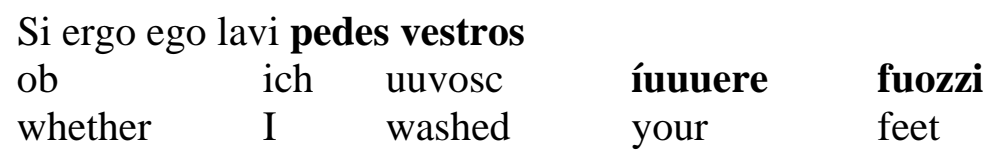

$\begin{array}{lllll}\text { a. non exies inde } & & & \\ \text { niges } & \text { thú } & \text { thanan } & \text { ús } & (\mathrm{T} \mathrm{63,15)} \\ \text { not-go } & \text { you then } & \text { out } & \end{array}$

b. a domino factum est istud

$$
\text { fon truhtine ist thaz gitan }
$$

5 „Ein zweites Prinzip ist, dass der Übersetzer in der Abfolge der Satzglieder lieber die nichtdeutsche Stellung der grammatischen Funktionswörter wie Hilfsverben und Personalpronomen als die nichtdeutsche Stellung der inhaltsschweren Wörter wie Substantive und Vollverben verändert.“ [ A second principle is constituted by the fact that the translator rather changes the (ungerman) order of grammatical words like auxiliaries and pronouns than the (ungerman) order of content words like nouns and main verbs]. 


$$
\text { by the-lord is that done }
$$

These observations by Dittmer \& Dittmer have generally been taken to show that the deviations always go towards the NHG grammar and that deviations from NHG should be relegated to adherence to the Latin origin. Dittmer \& Dittmer do not address the question of whether the regularity with which light elements are preposed and heavy constituents remain in their (postverbal) position could not be due an original OHG system.

The question becomes especially relevant as a close inspection of the data in the Tatian translation reveals that there are numerous deviations from the Latin original that are not compatible with the grammar of NHG since they yield word orders which are highly marked or ungrammatical in NHG. Some of these examples are of particular relevance since they involve deviations from Latin word orders, which from the viewpoint of NHG-grammar were already optimal. We will have a careful look at these cases in the following section.

\subsection{Systematic Deviations differing from NHG}

If the deviations from the Latin original only went towards the NHG-grammar, as is insinuated by Dittmer \& Dittmer, then one would not expect that a V2-clause in the Latin original is replaced by a non-V2 clause. Likewise one would not expect that verbs in final positions in embedded clauses in the Latin origin are replaced by orders which place constituents after the verb. However, such cases are not rare at all and it can be shown that these deviations are systematic and reveal a genuine OHG system.

\subsubsection{Main clauses}

Let us first have a look at declarative main clauses. Declarative main clauses in NHG require V2. As we have seen above V2-patterns are indeed created regularly against the Latin original. Besides these cases, however, a great number of examples can be found in which the word order of the Latin origin is changed into V1-order or, less frequently, into V3-order in main clauses.

In this paper I will confine myselves to the cases with V1-order showing that this pattern appears only in specific contexts and with a particular group of predicates (cf. Hinterhölzl \& Petrova 2005). The contexts that regularly trigger V1 are text-initial sentences, as is illustrated in (15), and sentences that introduce a new discourse referent (16).

(15) factum est autem In diebus illis

$\begin{array}{llll}\text { Uuard } & \text { thô gitân In then tagon (T 35, 7) } \\ \text { became } & \text { then done in those days }\end{array}$

(16) Vidua autem quædam erat/ In ciuitate illa

uuas thar ouh sum uuitua/ In thero burgi (T 201, 2)
was there also some widow in that town

The types of predicates that regularly trigger V1-order are verbs of motion, verbs of saying and inchoative verbs that signify a physical or psychological change of state. Leaving aside inchoative verbs for the moment, the rest of these predicates can be analysed as signalling a change of Place, Time or Person. Assuming that discourse situations are indexed for the variables Speaker, Place, Time and discourse referents, V1-orders can be analysed as indicating a change of discourse situation or simply as indicating a new discourse situation.

\subsubsection{Dependent clauses}


Considering adverbial clauses and relative clauses, it is noteworthy that the Tatian translation quite frequently deviates from the verb final pattern grammaticalized in NHG. Here we are interested in cases in which the Tatian translation deviates from the Latin original but, instead of the verb final pattern to be expected, displays an order in which the finite verb, in many cases an auxiliary, precedes a constituent that is more important from an informational point of view, as is illustrated in (17) and (18).

(17) [Lucerna corporis .est oculus./] si fuerit oculus tuus simplex./ totum corpus tuum lucidum erit.

[Liohtfaz thes lihhamen ist ouga/] oba thin ouga uuirdit lutter/

thanne ist al thin lihhamo liohter (T 69, 22ff)

[The light of the body is the eye.] when your eye becomes light

then all your body is light

(18) [ouem] \& si ceciderit sabbato in foueam/ nonne tenebit...

[ein scaf] Inti oba íz bifellit in sambaztag in grouba/

nibi hér nehme... (T 106, 27ff)

[a sheep] and when it falls on Saturday in a ditch,

he should not take...

A similar strategy is evident in embedded clauses that correspond to a nominal expression or a participial construction in the Latin original. Since verb placement in these cases cannot be influenced by the Latin original, it is reasonable to assume that these (freely built) structures display genuine OHG word order. A number of these cases indicate that this genuine word order cannot simply be equated with the verb final pattern, as is illustrated in (19-20). Also these cases can be subsumed under the rule that we noted to be relevant in (17-18): the light verb or auxiliary precedes the predicate noun, which is associated with the new information.

(19) [\& ecce homo erat In hierusalem.]'/ cui nomen simeon

senonu tho uuas man In hierusalem.' $/$

thes namo uuas gihezzan Simeon (T 37, 23ff.)

[behold there was a man in Jerusalem]

of- name was named Simeon

(20) Beati misericordes

salige sint thiethar sint miltherze (T 60, 12)

blessed are those that are mercyful

The most convincing cases for displaying a genuine OHG word order are those in which the verb-final pattern in the Latin original is replaced with a non-verb-final pattern in the translation in embedded clauses. Note that this phenomenon can be found in all types of embedded clauses, in complement clauses as well as in adverbial clauses, although it appears most frequently in relative clauses. Examples of this type of word order deviations are given in (21-22) for adverbial clauses, in (23-25) for relative clauses and in (26) for complement clauses.

(21) ut in me pacem habeatis

thaz in mir habet sibba (T 290, 8)

that in me you-have peace 
(22) nisi conuersi fueritis. / \& efficiamini sicut paruuli

nibi ir uuerdet giuuentite /[inti gifremite soso theser luzilo](T 151, 12)

if-not you become converted [and do as this little (one)]

(23) [domine ego credidi/ quia tu es christus filius die/]

qui in mundum uenisti

(trohtin ih giloubta./ thaz thu bist crist gotes sun./)

thie dar quam in mittilgart (T 231, 18ff.)

[Lord, I believe that you are Christ, son of God]

that there came to the world

(24) [\&obtulerunt ei/ omnes male habentes/ [...]]/ \&qui demonia habebant

Inti bráhtun imo/ alle ubil habante / [...]]/

Inti thie thár hab\&un diuual $(\mathrm{T} 59,1)$

[and brought to-him all evil-bearers]

and those that had devil

(25) [Iudex quidam erat In quadam ciuitate]/ qui deum non timebat

sum tuomo uuas In sumero burgi/ ther niforhta got (T 200, $31 \mathrm{ff}$ )

[a judge was in a city]

who not-feared god

(26) a. [gaud\&e autem]/ quod nomina uestra scripta sunt/ in caelis

giueh\& uúarlihho/ thaz íuuere namon sint giscribane/

in himile (T 103, 26ff)

[rejoice truly] that your names are written-down

in heaven

b. quia magnificauit dominus misericordiam suam/ cum illa

thaz truhtin mihhilosiota sina miltida/ mit Iru (T 30, 19-20)

that the-lord enlarged his mercy with her

c. non resistere malo

$\begin{array}{llll}\text { thaz } & \text { ír } & \text { niuuidarstant } \& & \text { ubile } \\ \text { that } & \text { you } & \text { not-withstand } & \text { (the) evil }\end{array}$

Summing up, we have seen that in all types of dependent clauses, including adverbial clauses, relative clauses and complement clauses, we find a number of cases which display a word order in which the finite verb or auxiliary precedes a constituent, often a nominal, verbal or adjectival predicate which constitutes new information. As is evident in (21), (22), (23), (25) and (26ac), these constituents, while being 'heavy' from an informational point of view, need not be heavy constituents from a prosodic point of view.

\section{$4 \quad$ Interpreting the Pertinent Variation in Word Order}

In this section, I would like to take a closer look at deviations from both the Latin original and from NHG in order to sketch out more precisely the regularities behind these deviations and to show that they are part of a genuine OHG grammatical system in which word order is predominantly determined by information-structural requirements.

I will concentrate here on the restrictions on word order in the right periphery, but before this we will take a look at word order variation in the left periphery in the following 
section, since the account of the alternation between V1- and V2-clauses will provide us with a clue for the correct analysis of relative clauses in OHG.

\subsection{The Relation between V1- and V2-clauses}

In this section, I will investigate whether the alternation between V1- and V2-clauses can be given a systematic account. In the previous section, we have noted that V1 clauses are used to introduce new discourse situations. This intuition shall be given a more formal account below.

Interpreting V1- and V2-clauses in their context, it becomes evident that verb placement in the Tatian translation correlates with different discourse relations (cf. Hinterhölzl \& Petrova 2005). In their analysis of the different discourse-roles of clauses in different types of texts, Asher \& Lascarides (2003) distinguish between two basic types of discourse relations, namely between subordinating and coordinating discourse relations.

Putting aside interrogative clauses, the V2-pattern appears in the Tatian translation in sentences that provide additional information about a previously established discourse referent. In other words, the finite verb serves to separate the topic (in the sense of Reinhart (1981)) from the comment provided by the rest of the sentence. The V1-pattern, in turn, appears in sentences which lack an information-structural partition in topic and comment but serves to push forward the main story line by introducing new discourse situations. According to the theory of Asher \& Lascarides (2003), V2-clauses express subordinating discourse relations: the comment provides further information about a given discourse referent (elaboration), while V1-clauses express coordinating discourse relations by marking the transition from one discourse situation to the next one (narration) (see Hinterhölzl \& Petrova 2005 for further details).

Thus the alternation between V1- and V2-clauses can be given a systematic explanation in terms of discourse relations.

\subsection{The Deviations from V-final placement in embedded clauses}

If we first have a look at the deviations in relative clauses - since they also constitute the largest group of exceptions - then given what has been said above about the dependence between placement of the finite verb and discourse relations, two possible explanations suggest themselves.

A) The explanation that was already hinted at in Section 3 is that in embedded clauses the light verb precedes the heavier predicate.

B) The alternative explanation is based on the assumption that the relative pronoun in OHG still acts like a demonstrative pronoun that is to be analysed as the Topic of the embedded clauses and refers back to a discourse referent that has been introduced in the main clause. In this analysis the relative clauses expresses a subordinate discourse relation (Elaboration) and can be analysed according the pattern: Topic (anaphoric) Vfin Comment.

While the alternative explanation would work for examples like (21) and (23), which can be analysed as appositive relative clauses, it cannot account for the parallel facts in (18) and (22), where the relative clause has a restrictive interpretation, which means that the relative clauses erstwhile contributes to the establishment of a reference that is already presupposed in the analysis in B) above.

However, all relative clauses can be analysed according to the explanation in A) above. Since this explanation can be extended to the analysis of the placement of the finite verb in the other types of embedded clauses, the rule that governs word order in the right periphery must be taken as one that demands that light constituents precede heavy constituents. In the following section, I will take up the question from Section 2 above of 
whether this descriptive generalisation is better explained in terms of Behaghel's Law or in terms of information-structural restrictions.

\subsection{The Relevance of Prosodic and Information-structural Restrictions}

In this section, I will show that the word order in OHG is primarily subject to information structural restrictions. To this end, I will first argue that Behaghel's law is systematically outruled by information structural requirements. I will then show that it can be derived from a (violable) interface condition that applies in the mapping between syntactic structure and prosodic structure.

First recall that (8) and (9), repeated here as (27a) and (27b) for ease of reference, make slightly different predictions. In particular, (27a) predicts that a) light elements, that is, non-branching constituents precede the verb independently of their information structural role in the clause and that b) heavy, that is, branching constituents follow the verb irrespective of their IS-role in the clause. Both predictions turn out to be wrong.

(27) a. Light elements precede heavy elements in OE, OI and OHG. (Behaghel 1932: Das Gesetz der wachsenden Glieder)

b. C background $\mathrm{V}$ focus

In what follows I will analyse the information-structural role of constituents that have been either preposed (into the middle field) or postposed into the postverbal domain in embedded clauses. Needless to say that preposed heavy constituents and non-preposed light constituents are of particular interest here. Since Dittmer \& Dittmer (1998) have ordered and listed all cases of deviations, their study can be taken as a realiable basis for this small-scale empirical investigation.

According to Dittmer \& Dittmer (1998), there are 142 cases in which a constituent is moved from the postverbal field into the preverbal field in an embedded clause. The majority of these cases involve a pronominal subject or object that can be equally analysed as prosodically light and as discourse anaphoric. Among the 30 cases with a nominal subject, there are 23 cases that involve a branching constituent that must be analysed as heavy (the rest are biblical names like David, Herodes, Johannes, etc.). These heavy subjects, however, are to be analysed as belonging to the background and are constituted by combinations of a determining pronoun and a common noun like ther heiland, min fater and so on. Two cases are illustrated in (28). In both cases, thas magatin and thiu fluot have been introduced in the previous discourse.

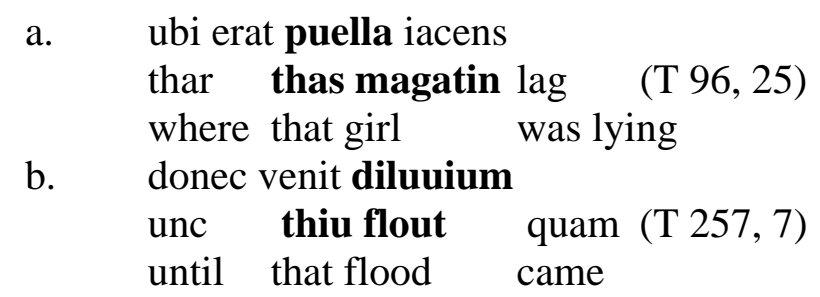

It is interesting to note that the number of preposed objects is relatively small compared to the number of preposed subjects. Dittmer \& Dittmer (1998) only list 8 such cases. Two cases involve the demonstrative pronoun then, translating the Latin personal pronoun eum ('him'), which is necessarily discourse anaphoric. Among the remaining 6 cases, 3 involve the preposing of a (light) noun and 3 involve the preposing of a (heavy) noun phrase. The latter, however, are mentioned in the previous discourse. 
If, in turn, we investigate the deviations in which a constituent is postposed from the middle field, then it must be noted that among the few 10 cases to be found (in very few cases a middle field can be identified in Latin), there are 7 cases that involve a non-branching constituent which cannot possibly be analysed as prosodically heavy. However, if we consider the information-structural role of these constituents, we note that they must be analysed as being focused, as is illustrated in (29).
Haec locutus sum vobis
ut in me pacem habeatis
thisu sprahih iu
in mundum presuram habebitis
thaz in mir habet sibba (T 290, 10)
in therru weralti habet ir thrucnessi
'this I tell you that in me you-have peace in the world you-have unrest'

In (29), which puts into the context the example (21) above, the non-branching direct object is postposed, while the branching PP remains in the middlefield. The information structural analysis, however, reveals that this configuration is to be expected since we are dealing with contrastive statements in which the PPs represent contrastive topics and the direct objects provide the corresponding focused constituent. ${ }^{6}$

The example in (30) shows that word order in the Tatian translation cannot be explained with the simple rule that pronominals are preposed, while DPs remain in their base position in accordance with the Latin original. In (30), a weak pronoun has been placed in the postverbal domain against the Latin origin. However, the context makes clear that the postposed pronoun is focused. The text passage requires that the pronoun be stressed. While modern German would use a focus particle (to strengthen the reflexive pronoun that cannot be stressed) - wer sich selbst erniedrigt, der wird erhöht werden - in OHG this focus is expressed syntactically by moving the pronoun into a right-peripheral focus position.
Quia omnis
qui se axaltat
humiliabitur
qui se humiliat exaltabitur

\section{bidiu uuanta iogiuuelih (T 195, 16) \\ thiedar sih arheuit \\ uuirdit giotmotigot}

inti therdar giotmotigot sih wirdit arhaban

and the one that humiliates himself will-be lifted

'therefore everyone that exalts himself will be humiliated but the one that humiliates himself will be uplifted'

In conclusion, we have seen that Behaghel's law is fullfilled if the syntax including information structure does not impose more specific restrictions on its own. In this case, light elements are moved into the preverbal domain, while heavy elements move to or remain in the postverbal area.

This conclusion is further strengthened by the following observation. A careful analysis of the data in the Tatian translation also reveals that the generalisation in (27b) needs to be refined in as much as contrastive foci are concerned. While new information focus is typically realized in postverbal position, as we have seen above, contrastive focus is realized in preverbal position, as is illustrated in (32) and (32).
tu autem cum ieiunas/ unge caput tuum/ \& faciem tuam laua/ ne uideatis hominibus/ ieiunans. Sed patri tuo
thane thu fastes/ salbo thin houbit/ Inti thin annuzi thuah/ zithiu

\footnotetext{
${ }^{6}$ An anonymous reviewer points that the focused elements in (29) are contrastive and should be placed postverbally according to the generalization in (33). However, the contrast in (29) involves an opposition between the topical elements in me and in the world, while the postverbal constituents simply provide new information.
} 


thaz thu mannon nisís gisehan/ fastenti.
úzouh thimeno fater
that you to-men

'[when you fast, do not be like the hypocrites ...] when you fast, anoint your head and wash your face so that you do not appear to men to be fasting but to your Father'

Note that in (31) the contrastive element mannon is placed preverbally against the order in the Latin original, signifying that we are dealing with an independent requirement of OHG. In this context it is interesting to note that PPs that are placed predominantly postverbally in accordance with Behaghel's law (due to their heaviness) appear preverbally when contrastively focused, as is illustrated in (32). The PP in (32) comprising three words is rather heavy, but nevertheless appears preverbally due to its interpretation as a constituent bound by a focus operator like 'only'.

(32) orantes autem. nolite multum loqui/ sicut \&hnici.'/ putant enim quia in multiloquio/ exaudiantur.

b\&onte nicur\& filu sprehan/ sósó thie heidanon mán/ sie uuanen

thaz sie in iro filusprahhi / sín gihórte $T(67,23-26)$

that they in their many words are heard

'And when you pray, do not use vain repetitions as the heathens do. For they think that they will be heard (only) for their many words'

Therefore, the generalization in (27b) that explains ( in tandem with Behaghel's law) the variation in word order found in the Tatian translation needs to be slightly revised, as given in (33).

C background

contrastive focus $\quad \mathrm{V}$ information focus

In this respect, OHG seems to pattern with Yiddish, which is a West Germanic language that has preserved mixed word orders. According to the description of Diesing (1997), constrastive foci pattern with background elements in occupying a preverbal position. Now, the question arises of which assumptions the pattern in (33) can be derived from. The pattern certainly calls for a syntactic representation of focus in OHG that distinguishes between contrastive focus and information focus. Given the UBH, arguments must be taken to move out of the VP to be licensed in (Case-) Agreement positions. If we then assume that a structural focus position is located above these licensing positions, the word order facts in (33) follow from the following requirements on the syntax of focus: A) The verb moves into the Focus head. B) A contrastively focused phrase moves into [Spec,FocP]. C) A constituent that represents new information focus just stays in the scope of the Focus head while D) background elements move out of the scope domain of the Focus head (see also Hyman \& Polinsky this volume and Skopeteas \& Fanselow this volume). This is illustrated in (34).

Assumptions about the syntax of focus (Hinterhölzl 2004) ${ }^{7}$

[C Background [FocP ContrastFocus V [AgrP InformationFocus [vP]]]]

According to (34), word order in OHG obeys the same restrictions as word order in Yiddish. Yiddish is analysed as a VO-language by Diesing (1997), since the preverbal position is preferred for strong DPs, while weak DPs tend to appear in postverbal position. Given that the VP is analysed as the domain of existential closure (Diesing 1992), the base position of

\footnotetext{
${ }^{7}$ See also Hyman and Polinsky (this volume) for arguments against a unique focus position in Aghem. The present proposal makes OHG (and Yiddish) look a lot like focus-licensing in Hungarian (cf. K. Kiss (1996)).
} 
arguments must be taken to be postverbal. Haider \& Rosengren (2003), applying the tests for OV/VO-properties of Vikner (2001), analyse Yiddish as an OV-language. In their approach the OV/VO-distinction signals a difference in the base structure: arguments in VO-languages are projected in vP-shells, while arguments in OV-languages are projected in stacked adjunction structures, as is illustrated in (35a-b).

$$
\begin{aligned}
& \text { a. } \left.\quad\left[\begin{array}{llll}
\mathrm{SU} & \mathrm{v}-\mathrm{V} & {[\mathrm{IO}} & {[\mathrm{t} \mathrm{DO}}
\end{array}\right]\right] \\
& \text { b. [SU [IO [DO V]]] }
\end{aligned}
$$

To account for the postverbal occurrence of arguments in Yiddish, they assume that Yiddish possesses an additional vP-shell (normally only available in VO-languages in their account) and optional verb movement into this additional head position. To highlight the particulars of the present approach, I will compare it with Haider \& Rosengren's (2003) account. While Haider \& Rosengren (2003) assume a directionality parameter that is operative in the base, namely the directionality of argument-licensing within the vP (that forces the projection of vP-shells in VO-languages), I assume a universal VO-base order in which unmarked word order is determined by information-structural and prosodic requirements. In particular, I propose that directionality is a prosodic property and thus only comes into play at the syntaxprosody interface.

The distribution of DP-types in Yiddish (and OHG) can be explained by assuming VO-base order and the information structural restrictions given in (34) above. This account is superior to Haider \& Rosengren's (2003) account, since they provide no obvious way of connecting verb placement and focussing. The OV-properties of Yiddish in the present account are treated as superficial properties derived in the syntax-prosody interface. As we will see in the following section, an important restriction on word order has to do with the headedness of phonological phrases. The preverbal placement of (separable) verb particles in Yiddish, which is treated as one of the main arguments by Vikner (2001) for the OV-character of Yiddish, follows from the direction of phonological restructuring of the verb in the present account. Assuming that constituents that build a complex predicate with the verb must form a prosodic unit with the verb, the preverbal occurrence of predicates follows from the directionality of phonological restructuring of the verb (towards left): a property that I propose is induced by the predominant direction of focus-restructuring (cf. section 2.4 above).

In the following section, I will discuss what restrictions may lie behind Behaghel's law. The approach that I will pursue is that Behaghel's law is due to a violable interface condition that restricts the mapping between syntactic structure and prosodic structure and is phase-bound in its application.

\section{$5 \quad$ Interface Conditions and Unmarked Word Order}

The first question that arises with Behaghel's law, namely how to properly define heaviness, I have already tacitly answered by equating heaviness with a branching constituent. In the following, I will propose that Behaghel's law should be properly understood as flowing out of a condition that defines the best match between syntactic structure and prosodic structure.

The account that I am going to develop should also explain the data in (5) and (6) above, repeated here for convenience in (36)-(37). The data in (36)-(37) display again the contexts in which we argued above that heaviness plays a role in cases of word order differences between language types.

(36) a. John (more) often (* than Peter) read the book

b. Hans hat öfter (als der Peter) das Buch gelesen 
The goal of this approach is not to develop special conditions for VO-languages, as Haider (2004) does in proposing a specific edge effect in adjunct placement in English, but to propose a universal constraint that can also be taken to hold in OV-languages.

\subsection{A phase-based prosodic condition}

In this subsection, I will outline a constraint that applies in the V-domain in German and will then argue that the same constraint can explain the data in (36)-(37) in English. The mechanism that I will employ is that prosodic mapping applies phase-wise such that one and the same constraint can be argued to apply in the V-domain in a language, but may fail to apply in another domain in this language, for instance in its I-domain, or middle field.

Note that there is a peculiar restriction that applies in the V-domain in German, that is to say, in verb clusters. German verb clusters are predominantly left-branching, but rightbranching verb clusters are possible as long as the most deeply embedded cluster is leftbranching (cf. Hinterhölzl 1999). A case in question is given in (38a). However, once a rightbranching verb cluster is introduced, the verb cluster must also be right-branching at the next level up, as is illustrated by the contrast in (38b) and (38c).

$\begin{array}{llll}\text { a. weil er den Text } \quad \text { [muß [lesen können]] } & \\ \text { since he the text must read can } & \\ \text { 'since he must be able to read the text' } & \text { wird] } \\ \text { b.?? } & \text { weil er den Text [[müssen [lesen können]] } & \text { will } \\ & \text { since he the text must read can } & \\ \text { 'since he will have to be able to read the text' } & \end{array}$

The formation of verb clusters is motivated by the following two licensing requirements (cf. Hinterhölzl (2006): dependent verbs move into dedicated positions in the V-domain to be temporally linked and to check the subcategorisation of the selecting verb. $\mathrm{F}^{0}{ }^{2}$ is responsible for temporal linking and $\mathrm{Asp}^{0}$, the highest head in the $\mathrm{V}$-domain, is responsible for checking the subcategorisation of the matrix verb, as is illustrated in (39) below.

In this approach, left-branching verb clusters are derived if the dependent verbs are spelled out in the highest Specifier, as is illustrated in (39a), while right-branching verb clusters are derived if the dependent verbs are spelled out in the lower Specifier (39b). The only exception to this rule build verb clusters comprising an IPP-infinitive (an infinitive that replaces a part participle). These verb clusters are obligatorily right-branching, as is illustrated in $(39 c){ }^{8}$
a. $\quad$ [AspP [lesen können] muss [F2P [lesen können] [VP]]]
b. $\quad$ [AspP [lesen können] muss [F2P [lesen können] [VP]]]
c. $\quad[$ AspP
0-hat [F2P [lesen können ] [VP ]]]

\footnotetext{
${ }^{8}$ In Hinterhölzl (2006), it is argued that IPP-infinitives comprise a null morpheme that accounts for the selectional restriction of the auxiliary and the temporal interpretation of the IPP-infinitive and that it is this morpheme that moves to highest head in the V-domain of selecting auxiliary (indicated by the presence of the null morpheme $O$ in (39c)), thereby accounting for the fact that IPP-infinitives always involve right-branching verb clusters.
} 
The interesting question now is what the generalisation illustrated in (38bc) results from. In any event, the generalisation cannot be derived from a hard syntactic condition in West Germanic, since we can find many instances that violate it, as is the case with IPP-infinitives in West Flemish. (40) illustrates a right-branching verb cluster headed by willen which itself sits on a left-branch with respect to the selecting auxiliary een.

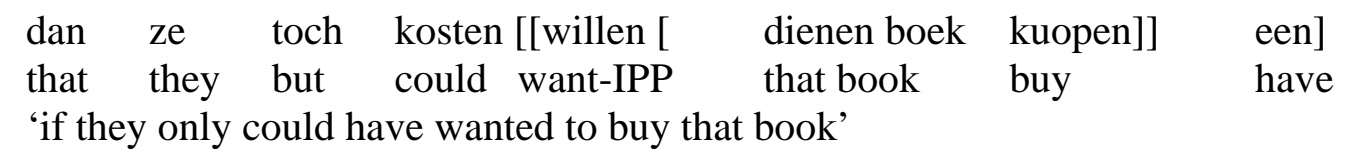

A possible solution is to relegate the contrast in (38bc) to a violable interface condition that determines the best match between a given syntactic structure and a prosodic output structure. Given that left- and right-branching verb clusters are mapped onto left- and right-headed phonological phrases, a possible candidate for such an interface condition is (41).

(41) Mapping Condition between syntactic structure and prosodic structure:

A right-headed phonological phrase (in a verb cluster) must sit on a right branch with respect to the syntactic head that is to become its prosodic sister

(41) can probably be formulated in a more elegant way. But it is meant to account for the patterns in (42). The patterns in (42) indicate the deeper reason that probably lies behind the condition in (42): once fixed, stress tends to stay in a peripheral position within a certain domain.

(42b) is okay since stress remains left-peripheral and (42c) is okay since stress remains right-peripheral, while stress in (42a) is neither left- nor right-peripheral unless $\mathrm{H}$ itself is stressed. (38b) violates the condition in (41). The violation can be circumvented if the (already) right-branching verb cluster is spelled out in the lower Specifier as is the case in (38c). In other words (41) ensures a transparent, that is, monotonous mapping between syntactic structure and prosodic structure.

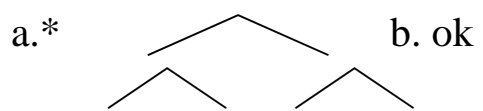

$((\mathrm{A}$

B) $\mathrm{H})$ b. ok

$((\mathbf{A}$

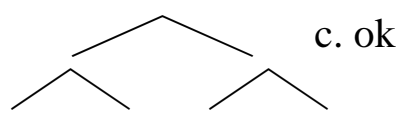

B) $\mathrm{H})$

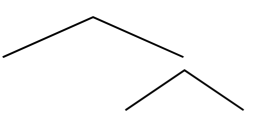

$\left(\begin{array}{lll}\mathrm{H} & (\mathrm{A} & \mathbf{B}\end{array}\right)$

However, this condition must be taken to be restricted to the V-domain in German. The crucial evidence comes from restrictions on VP-topicalization in German. As is illustrated in (43), topicalized right-branching verb clusters exhibit an interesting contrast. In general, the topicalization of a right-branching verb cluster leads to ungrammaticality unless it comprises an IPP-infinitive, in which case the topicalization is rather marked but grammatical.

a.?* [müssen [lesen können]] 'he will have to be able to read the text'
b.? [haben [lesen wollen]] have read want-IPP
wird er den Text will he the text
'he will have wanted to read the text'

wird er den Text (ok lesen können müssen wird) will he the text

The violation in (43a) cannot be accrued in the C-domain, since the C-domain in German does tolerate right-branching prosodic constituents. Thus the violation must have been induced in the V-domain. A violation of (41) can then be taken to be induced in a phase-based 
derivation if we make the assumption that the Aspect phrase (and not the vP as in Chomsky (2001) constitutes the edge of the strong vP-phase. Since we can assume that topicalization involves movement from one strong phase (the vP) into the next strong phase (the $\mathrm{CP}$ ), it must be taken to be subject to the Phase Impenetrability Condition, given in (44b).

Phase Condition (Chomsky 2001)

(44) a. Evaluation for a phase is done at the level of the next highest strong phase

b. $\quad$ Phase Impenetrability Condition (PIC)

The complement of a strong phase $a$ is not accessible to operations at the level of the next highest strong phase $b$, but only the head and the edge of $a$ are

Given the PIC, extraction of the right-branching verb cluster must take place via the highest Specifier in the V-domain, namely [Spec,AspP]. In this position, however, the verb cluster will induce a violation of the mapping condition in (41), which will result in ungrammaticality if there is an alternative that does not violate it. Since the verb cluster could have been spelled-out as a left-branching verb cluster (43a) is ungrammatical. Since IPP-infinitives only allow for right-branching verb clusters, there is no derivational alternative in the case of (43b), thus the resulting topicalization is prosodically marked but grammatical.

This solution, however, is only feasible in a framework in which spell-out applies cyclically, including the cyclic, that is, phasewise application of conditions that map syntactic structure onto prosodic structure (cf. Fery \& Ishihara this volume). More specifically, we have seen above that interface conditions can apply phasewise in the sense that they may hold in one phase (the V-domain in German) without holding in another phase (the I-domain, or middle field, in German).

\subsection{Interface Conditions and the OV/VO parameter}

Note that condition (41) is a condition that can be taken to apply in the V-domain and in the Idomain (excluding the subject) in VO-languages. In fact, (41) can be used to rule out (36a), since more often than Peter is a right-headed prosodic constituent that sits on a left branch with respect to the verb phrase that is to become its prosodic sister. Along the same lines, we may assume that event-related adjuncts are placed postverbally in English (cf. (37b) above), since their preverbal occurrence would induce violations of the condition in (41). This is why VP-intrposition is obligatory with heavy event-related adjuncts in modern English. The only exception are light, that is, non-(right-)branching adverbs, as is illustrated in (45).

(45) a. John carefully read the book

b. $\quad *$ John with care read the book

The fact that German tolerates heavy adjuncts (and arguments) in the middle field (cf. (37a) above) indicates that this condition cannot be taken to apply in the German middle field, but as we have seen above- is still active in the German V-domain.

Furthermore, note that the condition in (41) can be taken to be the basis of Behaghel' law, if we assume that it applied in the middle field in OHG, OE and in ON: while pronouns and single nouns do not induce violations of the condition in (41), the same condition would require modified nouns and PPs to be placed postverbally.

How can we explain the differential development of the three languages? In section 3, we have seen that the prosodic condition in OHG was regularly outruled by information structural requirements: discourse-given heavy DPs are regularly preposed, as are heavy constituents that receive a contrastive focus interpretation, while light elements were postposed when they were discourse-new or non-contrastively narrowly focused. This means 
that information-structural requirement led to the production of a high number of marked prosodic structures with the result that the prosodic constraint was restricted to the V-domain in German. Word order in the German middle field is subject to another interface constraint that guarantees scope transparency, as we will see below.

OV word order in an approach subscribing to the UBH must be taken to be derived by obligatory movement of vP-internal material into licensing positions in the middle field (cf. Hinterhölzl 2006). The reasons for motivating licensing movement out of the vP must also be taken to be valid in VO-languages. In the present framework we have two options to account for VO-orders on the surface: a) spell out in the lower base position (called silent scrambling in Hinterhölzl 2003) or b) spell out in the licensing position with vP-movement around it.

The second option can be excluded, since there is ample empirical evidence that VOorders in English cannot be derived by object movement that spells out the higher copy plus vP-movement around it. First note that the vP cannot be topicalized excluding the direct object, as is illustrated in (46). Furthermore, note that the object cannot be separated from the verb and appear in its scope position between adverbs, as is illustrated by the contrast between German and English in (47a-b). The intended reading of (47a) is possible in the order given in (47c), where the direct object arguably occupies a vP-internal position.

$$
\begin{aligned}
& \text { a. John wanted to buy something yesterday } \\
& \text { b. * and buy John did a book } \\
& \text { Hans wollte gestern etwas kaufen } \\
& \begin{array}{l}
\text {... und gekauft hat er heute ein Buch } \\
\text {... and bought has he today a book }
\end{array} \\
& \text { * John met every day two girls in their classrooms (Temp > DO > Loc) } \\
& \text { b. Hans traf jeden Tag zwei Mädchen in ihren Klassenzimmern } \\
& \text { bans met every day two girl in their classrooms } \\
& \text { c. John met two girls in their classrooms every day }
\end{aligned}
$$

The only option that remains is to assume that DPs that undergo licensing movement are spelled out in the vP in English. This option can be derived from the condition in (41), if we assume that (41) requires the spell out of arguments in the lower position. Haider \& Rosengren (2003) use the availability of scrambling as evidence for motivating a distinction in the base structure between OV-languages and VO-languages: in their account scrambling is only possible if arguments are projected in stacked adjunction structures, as illustrated in (35b) above. In the present account, there is no distinction in the base between between OVand VO-languages. Both language types are assumed to allow for scrambling, as is also evidenced by the parallel readings in (47b-c), but scrambling in VO-languages is argued to be silent due to an interface condition operating on the PF-side of the computation.

The contrast in (47) shows that word order in German displays scope in a transparent manner and can thus be taken to obey another interface constraint that restricts the mapping between syntax and LF.

Scope Transparency (cf. Hinterhölzl to appear)

If $a$ scopes over $b$, the spell out copy of $a$ should c-command the spell out copy of $b$

Information structure interacts with syntactic structure through the imposition of scope requirements, as outlined in (34) above. Obeying the information-structural requirements in (34) has weakened the application of the prosodic mapping condition in (41), but strengthened the scopal mapping condition in (48) in the history of German, leading to a language in which word order is fully scope transparent. 
In the history of English, on the other hand, the prosodic condition was retained or even reinforced in the middle field, leading to the development of a pure VO-language, that is to say, of a language that shows a large degree of PF-transparency as defined in (41).

In conclusion, word order variation can be accounted for by the differential expression of information structural categories within one grammar and word order preferences (Behaghel's law) are due to violable interface conditions that define the ideal mapping between syntactic structure and prosodic structure in the course of the derivation. Furthermore, I have argued that the distinction between OV- and VO-language should not be accounted for by a distinction in the base but can be reduced to the workings of two parallel interface constraints that define the optimal mapping from syntax to PF and from syntax to LF, respectively. Finally, I have laid out the historical conditions (cf. (34) above) that led German into developing into a scope transparent OV-language.

\section{References}

Asher, Nick and Alex Lascarides (2003). Logics of Conversation. Cambridge: Cambridge University Press.

Behaghel, Otto (1932). Deutsche Syntax. Band 4. Heidelberg: Carl Winters Universitätsbuchhandlung.

Biberauer, Theresa and Ian G. Roberts (2005). Changing EPP-Parameters in the History of English: Accounting for Variation and Change. English Language and Linguistics 9, 157-179.

Chomsky, Noam (2001). Derivation by Phase. In Michael Kenstowicz (ed.): Ken Hale- a life in language. Cambridge, Mass.: MIT Press.1-52.

Diesing, Molly (1997). Yiddish VP order and the Typology of Object Movement in Germanic. Natural Language and Linguistic Theory 15,369-427.

Dittmer, Arne \& Ernst Dittmer (1998). Studien zur Wortstellung-Satzgliedstellung in der althochdeutschen Tatianübersetzung. Göttingen: Vandenhoeck \& Ruprecht.

Fery, Caroline and Shin Ishihara (this volume). How Focus and Givenness Shapes Prosody.

Frascarelli, Mara (2000). The Syntax-Phonology Interface in Focus and Topic Constructions in Italian. Dordrecht:Kluwer Academic Publishers.

Haider, Hubert (2004). Pre- and postverbal adverbials in OV and VO. Lingua 114, 779-807.

Haider, Hubert (2000). Adverb Placement-Convergence of Structure and Licensing. Theoretical Linguistics 26: 95-134.

Haider, Hubert and Inger Rosengren (2003). Scrambling: Nontriggered Chain Formation in OV Languages. Journal of German Linguistics 15.3, 203-267.

Hinterhölzl, Roland (2006). Scrambling, Remnant Movement and Restructuring. Oxford: Oxford University Press.

Hinterhölzl, Roland (2004). "Language Change versus Grammar Change: What diachronic data reveal about the distinction between core grammar and periphery". In Eric Fuss \& Carola Trips (eds.): Diachronic Clues to Synchronic Grammar. Linguistik Aktuell 72. Amsterdam: John Benjamins.

Hinterhölzl, Roland (2002). Parametric Variation and Scrambling in English. In: W.Abraham \& J.W.Zwart (eds.): Studies in Comparative Germanic Syntax (Proceedings of CGSW 15 in Groningen, May 2000). John Benjamins, Amsterdam \& Philadelphia

Hinterhölzl, Roland (2001). Event-related Adjuncts and the OV/VO Distinction. In: K. Megerdoomian et Leora Bar-el. (eds): WCCFL 20 Proceedings. Cascadilla Press, Somerville.

Hinterhölzl, Roland (1999). Restructuring Infinitives and the Theory of Complementation. Doctoral dissertation. University of Southern California.

Hinterhölzl, Roland and Svetlana Petrova (2005). Rhetorical Relations and Verb Placement in 
Early Germanic Languages: Evidence from the OHG Tatian Translation. ACLProceedings of Multidisciplinary Approaches to Discourse. Chorin, 5.-8. Oct. 2005.

Hinterhölzl, Roland, Svetlana Petrova and Michael Solf (to appear). Diskurspragmatische Faktoren für Topikalität und Verbstellung in der ahd. Tatianübersetzung. In: S. Ishihara, M. Schmitz and A. Schwarz (eds.) Interdisciplinary Studies on Information Structure. Potsdam University.

Hroarsdottir, Thorbjörg (2006). Loss of OV and the role of morphology. Ms., Universitetet i Tromsö.

Hroarsdottir, Thorbjörg (2000). Word Order Change in Icelandic: From OV to VO. Amsterdam \& Philadelphia: John Benjamins.

Hyman, Larry and Maria Polinsky (this volume). Focus in Aghem.

Kayne, Richard (1994).The Antisymmetry of Syntax. Linguistic Inquiry Monograph 25. Cambridge, Massachusetts. MIT Press.

Kemenade, Ans van (1987). Syntactic Case and Morphological Case in the History of English. Dordrecht: Foris.

Kemenade, Ans van \& Nigel Vincent (1997). Parameters of Morphosyntactic Change. Cambridge: CUP.

Kroch, Anthony and Ann Taylor (2000). Verb-Object Order in Early Middle English. Ms. University of Pennsylvania.

Kroch, Anthony and Ann Taylor (1997). Verb Movement in Old and Middle English: Dialect Variation and Language Contact. In Kemenade, Ans van \& Nigel Vincent (eds.)Parameters of Morphosyntactic Change. Cambridge: CUP.

Lenerz, Jürgen (1984). Syntaktischer Wandel und Grammatiktheorie. Tübingen: Niemeyer.

Nespor, Marina and Irene Vogel (1986). Prosodic Phonology. Dordrecht: Foris Publications.

Nespor, Marina, Maria Teresa Guasti and Anne Christophe (1996). Selecting Word Order: The Rhythmic Activation Principle. In: Ursula Kleinhenz (ed.) Interfaces in Phonology. 1-26. Berlin: Akademie Verlag.

Pintzuk, Susan and Anthony Kroch (1989). The Rightward Movement of Complements and Adjuncts in the Old English of Beowulf. Language Variation and Change1:115-43.

Pintzuk, Susan (1999). Phrase Structures in Competition: variation and change in Old English word order. New York: Garland.

Roberts, Ian (1997). Directionality and word order change in the history of English. In: Ans van Kemende \& Nigel Vincent (eds.): Parameters of morphosyntactic change. Cambridge: Cambridge University Press, 397-426.

Trips, Carola (2002). From OV to VO in Early Middle English. Amsterdam \& Philadelphia: John Benjamins.

Vikner, Sten (2001). Verb movement Variation in Germanic and Optimality Theory. Habilitation Thesis, University of Tübingen. 